\title{
Feeding patterns, trophic structure and damming rivers effect: studies applied in freshwater environments in the Brazilian semi-arid region
}

\author{
Jônnata Fernandes de Oliveira - Jean Carlos Dantas de Oliveira - Louize Nascimento -
} Rogério Taygra Vasconcelos Fernandes • José Luis Costa Novaes • Danielle Peretti

JF Oliveira (Corresponding author)

Instituto Federal do Maranhão de Ciência e Tecnologia do Maranhão, Campus Avançado Carolina, Praça Santo Antônio, $n^{\circ}$ 93, Centro, 65980-000, Carolina, MA, Brazil.

email: jonnata.oliveira@ifma.edu.br

\section{JCD Oliveira • RTV Fernandes $\cdot$ JLC Novaes}

Universidade Federal Rural do Semi-Árido, Departamento de Ciências Animais, BR 110 - Km 47, Bairro Costa e Silva, 59625-900, Mossoró, RN, Brazil.

\section{Nascimento}

Universidade do Estado do Rio Grande do Norte, Departamento de Gestão Ambiental, Av. Prof. Antônio Campos s/n, Bairro Costa e Silva, 59625-620, Mossoró, RN, Brazil.

\section{Peretti}

Universidade do Estado do Rio Grande do Norte, Departamento de Ciências Biológicas, Av. Prof. Antônio Campos s/n, Bairro Costa e Silva, 59625-620, Mossoró, RN, Brazil.

Received: January 12, 2018 • Revised: February 02, 2018 • Accepted: February 02, 2018

\begin{abstract}
The knowledge of the fish trophic structure has been outstanding for providing relevant information on the functioning of the ecosystem in which they are inserted, mainly in dammed environments of semiarid regions that suffer constant changes in the level of water, resulting in alterations, especially in the feeding of the fish due to the variation of the food resources throughout the year, causing changes in the diet of the local ichthyofauna. Within this context, the objective was to describe the trophic categories of fish species in freshwater environments of the Rio Grande do Norte state. Seven trophic guilds were recorded: Detritivore/iliophagous, Insectivorous, Carcinophagous, Piscivorous, Herbivorous and Omnivorous. Through the results, it is observed that the fish species inserted in different environments of the state present the same food pattern, demonstrating flexibility on the diet, prevailing a generalist alimentary habit.
\end{abstract}

Keywords: ichthyofaunal, reservoirs, trophic guilds

\section{Introduction}

In the Brazilian semi-arid region, due to prolonged periods of drought and shallow soils, few aquatic environments remain flooded throughout the year, creating the problem of lack and low-quality water available for human consumption (Cardoso et al 2012). Thus, to overcome the periods of water scarcity, reservoirs were built to store water in the rainy season for human consumption (Vieira et al 2010). These reservoirs suffer a deficit in their water bodies, associated with low rainfall, long periods of drought and high evaporation rates, being able to change from completely dry to overflowing (Montenegro et al 2010). These changes influence in the life cycle of the species, especially in fish feeding, through fluctuations in the abundance of food resources throughout the year (Silva et al 2012). Environmental effects are often limiting to species development, since the environment encompasses a set of factors that affect animals directly or indirectly (Silva et al 2015).

In these environments, it is also common practice to introduce non-native fish species, to guarantee fishermen the sustenance of their families and to contribute to the increase of supply in the region (Gurgel and Oliveira 1987). Introduced fish are relevant threats, because these animals are key organisms in innumerable ecological interactions; widely distributed, highly mobile and adapted to the environment (Vitule 2009). As observed by Molina et al (1996) in the Redonda Lagoon, Rio Grande do Norte, the peacock bass, Cichla ocellaris, after being introduced caused severe impacts to the ichthyofauna, extinguishing several native populations of fish, extremely fast.

Another impact on the ichthyofauna of the reservoirs of the semi-arid region may occur through the transposition of the São Francisco River. Through two channels, North Axis and South Axis, the water will be taken to important reservoirs in the region: Armando Ribeiro Gonçalves, Entremontes, Pau dos Ferros and Santa Cruz, among others (Santana Filho 2008). In addition to modifying the physical and chemical characteristics of the water, transposition may alter fish fauna due to the introduction of new species, which may lead to changes or situations undesirable of quality or environmental conditions (Agra Filho 2010). It is important to note that invasive species can cause loss of ecosystem functions, such 
as: coastal resources and decomposing products, spawning sites and refuge for predators (Zohary and Ostrovsky 2011). In addition, the principle of competitive exclusion states that two or more species cannot coexist in the same niche competing for the same resource (Gause 1934). Invasive species, more tolerant of environmental oscillations, can eliminate the native ones. Thus, considering the abrupt reduction in the volume of reservoirs water and the low levels of dissolved oxygen, non-native species can prevail in the environment (Pompeu and Godinho 2006), and may lead to their extinction due to interspecific competition for breeding sites, refuge and food.

In this context, studies on trophic ecology in reservoirs are necessary. The studies on fish feeding make it possible to apply to either isolated species or to pairs of species, as well as to more complex population and communities (Velludo 2007). The description of the food items consumed by all fish species in a community is the starting point for the recognition of a natural trophic structure (Mazzoni et al 2010). It is necessary to know the trophic spectrum and the food activity of the species in their environment to achieve success in conservation efforts (Lima and Behr 2010).

Although reservoirs are common in the Brazilian semiarid region, few investigated about the impact of the flow fluctuation caused by dams. Small-scale studies in reservoirs in the semi-arid region show that fishes present changes in dietary utilization and trophic structure due to changes in resources affected by drought and oscillations in the volume of water in the reservoirs (Oliveira et al 2016a; Oliveira et al 2016b; Oliveira et al 2018). In addition, the lack of rainfall in recent years has aggravated the water scarcity, causing an exacerbated decrease in the volume of water in the reservoirs, and a change in composition and fish abundance (Sousa 2015).

\section{The studies on natural fish feeding}

The studies on natural fish feeding and the establishment of the trophic structure have been outstanding for providing relevant information about the functioning of the ecosystem in which they are inserted. With the possibility to understand the ecology of the species and their role in the ecosystem and to identify the factors that determine the pattern of fish feeding throughout their life cycle (Oliveira et al 2016b). In Brazil, in recent decades there has been an increase in studies related to natural fish feeding, with a higher concentration for the species of major commercial interest, mainly of rivers and lakes in the North, South and Southeast regions of the country. Knowing the diet and food interaction of fish in natural or artificial environments with the environment provides important ecological information, such as the mechanisms that allow the coexistence and exploitation of resources by several species (Goulding 1980) to understand the behavior of these species in face of changes in environmental conditions and food availability (Silva et al 2008).

Feeding studies also provide applications for isolated species, as observed by Santos et al (2014). The authors studied the food preference of juveniles of Oligosarcus hepsetus, in controlled environment. Or for pairs of species as observed by Tófoli et al (2010) for the sympatric species of Moenkhausia in a creek in the Center-West Region of Brazil. As well as for population and communities, as described by Souza et al (2017) with the species Plagioscion squamosissimus in the Santa Cruz reservoir, Apodi-Mossoró river basin. And communities such as the research on the diet of the ichthyofauna of the Itupararanga reservoir, located in the state of São Paulo, by Ribeiro et al (2014).

From the feeding data it is possible to obtain information on the basic aspects of the species biology, such as reproduction, growth, adaptation and survival, as well as to understand how individuals exploit, use and share the resources of the environment (Silva et al 2012). In addition to information on the interactions between species, and how the trophic guilds are distributed in space and time. Thus, studies on the diet of fish are of great importance because they are directly related to obtaining energy and help to understand the activities involved in the development, growth, reproduction and maintenance processes of the organism (Bonato et al 2012; Ribeiro et al 2014).

\section{Changes in diet and food structure}

Most freshwater fish species have a wide range of food strategies and tactics, consuming many items, favoring adaptations to the new conditions imposed by the environment (Hahn and Fugi 2007). Fish can improve their diet using the most energetic resources or through the consumption of food items with greater availability in the environment (Macarthur and Pianka 1966), which will depend on the fish's ability to seek, detect and ingest the prey (Abelha et al 2001). The diet can still be altered when fishes explore a new region in the environment (Gandini et al 2014). Due to spatial and seasonal modifications of the habitat, considering that distinct locations and periods have different abiotic and biotic conditions (Abelha et al 2001) and from opportunistic behavior, from substituting scarce items for others abundant (Davies et al 2008).

The composition and distribution of the species that make up the trophic guilds in the community are dependent on several factors such as habitat structure, food availability (Ross 1986), community species richness and composition, interspecific and intraspecific relationship, and factors environmental (Ximenes et al 2011). Thus, guilds are characteristic of place and period and influenced by habitat structure, due to landscape change, erosion and deposition of sediment, which create local peculiarities (Allan 2004). Due 
to these factors, dietary variations are predictable and gradual, but abrupt changes in the environment such as those caused by the dams (Hahn and Fugi 2007) and by oscillations in the water volume of the reservoirs (Petry et al 2013) that cause situations unpredictable for which only species with higher food plasticity are adapted (Hahn and Fugi 2007). These changes alter the physic-chemical characteristics of the water, in which fish constitute the most affected group (Young et al 2011; Loures and Pompeu 2012).

The main effect of damming is the change in the natural runoff regime, which leads to a change in the amount of food resources and their use by the fish, which generally modifies the trophic dynamics of the environment (Hahn and Fugi 2007; Abujanra et al 2009). The dam constitutes an environmental filter for the species that, after damming, must find the food resources in the reservoir for its individual maintenance (Mérona and Vigouroux 2006), in this way, changes in the fish composition may occur.

Due to these processes, some food sources undergo rapid changes, which are perceived by all aquatic communities, thus algae, vegetables, zooplankton, zoobentos and fish undergo changes in their abundance and, consequently, availability for their consumers (Agostinho 1999). These changes inevitably have the growth of some opportunistic fish species, which replace scarce food items with more abundant ones (Davies et al 2008) and decrease and/or elimination of some species (Novakowski et al 2007), generating changes of fish composition (Hahn and Fugi 2007). Thus, the reservoirs can cause a disruption in the composition of the guilds, through the introduction of new predators or elimination of some ichthyofaunistic components, which can modify the cascade relationships related to bottom-up and topdown effects (Carpenter and Kitchell 1993), and negatively influence the entire aquatic ecosystem.

Another striking feature in these reservoirs is the presence of flows, in which they varied in an acyclic way, which leads to changes in the limnological characteristics of flooded areas, so that the fish respond differently to the environmental variations imposed. The excessive reduction of the level of the water of the reservoirs is a problematic that calls attention, because with the low level can cause an impact in the coastal region and in its surroundings, which can result in loss of the coastal zone, nursery and refuge for juveniles, with resulting loss of biodiversity (Winfried 2004). According to Gandini et al (2014), the impact of the flow fluctuation caused by dams is still poorly understood. Some authors demonstrate the effects of flow oscillations on the abiotic variables and the attributes of the fish assemblages, which influences their composition, abundance (Petry et al 2013), feeding (Medeiros et al 2014) and trophic structure (Corrêa et al 2009).

Feeding and trophic guilds of fish in the Brazilian semiarid
Considering that in the semi-arid region, low annual precipitation affects the trophic categories of fish and the need to understand these processes, it was intended with the review to describe the trophic guilds of the fish species in sweet environments of the state of Rio Grande do Norte. The review will be restricted to these environments because they are subject to seasonal fluctuations associated with temperature, water level, rainfall regime, which alter the available food resources, resulting in changes in fish diet in different locations.

In the guild detritivore/iliophagous are species with predominance of detritus/sediment in the diet. The Steindachnerina notonota (Miranda Ribeiro, 1937) in the reservoirs of Riacho da Cruz (Teixeira and Gurgel 2004) and Pau dos Ferros (Oliveira et al 2016a) was listed. Hypostomus pusarum (Starks, 1913), in the Marechal Dutra reservoir (Pessoa et al 2013) and in Santa Cruz reservoir (Oliveira et al 2016b). Prochilodus brevis (Steindachner, 1875) and Loricariichthys derbyi (Fowler, 1915) in the Pau dos Ferros reservoir (Oliveira et al 2016a). Loricariichthys platymetopon (Isbrucker and Nijssen, 1979) in the Santa Cruz reservoir (Oliveira et al 2016b) and Curimatella lepidura (Eigenmann and Eigenmann, 1889) in the Santa Cruz and Pau dos Ferros reservoirs. The detritus/sediment resource is very valuable for these species that present great ecological importance to these ecosystems, since they contribute to the cycling of nutrients from the environment (Oliveira et al 2016b).

Insectivores, represented by fishes that feed predominantly of insects. In this guild are Astyanax bimaculatus (Linnaeus, 1758) in the Boa Cicca Lagoon (Canan et al 1997), in Jiqui Lagoon (Gurgel et al 2002) and the Pau dos Ferros reservoir (Oliveira et al 2016a). Crenicichla lepidota (Heckel, 1840) in the Redonda Lagoon (Gurgel et al 1998). Triportheus signatus (Garman, 1890) in the Jiqui Lagoon (Gurgel and Canan 1999) and in the Santa Cruz reservoir (Oliveira et al 2016b). Trachelyopterus galeatus (Linnaeus, 1766) in the Santa Cruz reservoir (Oliveira et al 2016b). Astyanax fasciatus (Eigenmann, 1908) and Moenkhausia dichroura (Kner, 1858) in the Pau dos Ferros reservoir (Oliveira et al 2016a).

Carcinophagous is composed of species that present essentially shrimp in their diet. In this guild, Plagioscion squamosissimus (Heckel, 1840) was registered in the Piató Lagoon (Gavilan-Leandro et al 2009) and Santa Cruz reservoir (Souza et al 2017). This species has been documented with great trophic and opportunistic plasticity (Santos et al 2014; Ferreira Filho et al 2014). Research carried out in reservoirs in other regions indicates $P$. squamosissimus with piscivorous habit, as in the Paranapanema and Tibagi rivers (Bennemann et al 2006), Tietê (Stefani and Rocha 2009) and Sobradinho reservoir (Santos et al 2014). However, this species was also classified as carcinophagous in the ecological station reservoir 
of Tapacurá (PE) (Ferreira Filho et al 2014). Therefore, the diet of this specie in the state of Rio Grande do Norte, is possibly related to the abundance and availability of shrimp Macrobrachium amazonicum (Heller, 1862) in its reservoirs, facilitating its predation. Following the theory of optimal foraging proposed by MacArthur and Pianka (1966), in which the organisms are adapted to obtain food with the highest energy value by expending as little energy as possible.

In the herbivore, species with predominance of vegetables in their feeding are classified. In this case, Astyanax bimaculatus was recorded in the Santa Cruz reservoir (Oliveira et al 2016b). However, recent study by Oliveira et al (2018) in the Umari reservoir, recorded $A$. bimaculatus as insectivorous. The species Leporinus taeniatus (Fowler, 1941), Leporinus elongatus (Valenciennes, 1850) in the Pau dos Ferros reservoir (Oliveira et al 2016a) and L. piau in the Santa Cruz reservoir (Oliveira et al. 2016b) were also documented in the herbivorous guild and in the Pau dos Ferros reservoir (Oliveira et al 2016a). However, Durães et al (2001) attribute Leporinus species as omnivorous. This demonstrates trophic plasticity for the species.

The piscivorous presents fish as the main item in its diet. This guild was included Hoplias gr. malabaricus (Bloch, 1794), native species of the semi-arid region, in the Santa Cruz (Oliveira et al 2016b) and Pau de Ferros reservoirs (Oliveira et al 2016a), and Cichla monoculus (Spix and Agassiz, 1831) in the Santa Cruz reservoir (Oliveira et al 2016b). The studies on the food habit of $C$. monoculus in dammed environments have recorded the diet of specie as specialized fish-eating (Gomiero and Braga 2004; Novaes et al 2004; Capra and Bennemann 2009).

The fish-eating habit for $H$. malabaricus in environments of neotropical regions is well documented in the literature (Corrêa and Piedras 2008). Experimental studies in mesocosms show that $H$. malabaricus plays an important role in trophic structuring and regulation of forage species in aquatic environments (Mazzeo et al 2010). Therefore, this species deserves special attention to studies aimed at the conservation of the ichthyofauna in dammed environments, especially those considered small and medium sized.

Carnivorous, composed of species that exclusively consume items of animal origin, such as Synbranchus marmoratus (Bloch, 1795) in the Marechal Dutra dam (Montenegro et al 2011). Serrasalmus spilopleura (Kner, 1860) in the Extremoz Lagoon (Raposo and Gurgel 2003); and Cichla ocellaris (Schneider, 1801) in the Boa Cicca Lagoon (Canan et al 1997). Sousa et al (2017) classified Trachelyopterus galeatus in the Santa Cruz and Umari reservoirs as carnivore, with predominance of mollusk and fish in both. These authors demonstrated that the predominance of a food item is related to the abundance of the resource, in which demonstrated the opportunism of the specie.
Omnivores present consumption of vegetal and animal origin in similar proportions. In this category, Gurgel and Canan (1999) recorded Leporinus piau as omnivorous with insectivorous tendency in the Jiqui Lagoon. Yet Montenegro et al (2011) studied the diet and population structure of L. piau in a dam in the semi-arid region of Paraiba and classified the specie as herbivorous with tending to the omnivore. Predation tactics, morphology, oral apparatus and food availability are directly related to food preference of species (MachadoEvangelista et al 2015).

The determination of trophic guilds of fish in tropical reservoirs is very complex (Oliveira et al 2016b), food resources are few, where the main items found are vegetables, aquatic and terrestrial insects, debris (allochthonous resources), besides the plankton, benthos and fish (autochthonous resources) (Gurgel et al 2005; Hahn and Fugi 2009). However, there may be temporal changes in the availability of these resources, influenced by the oscillations in the volume of water, mainly associated with the rainy season, when the water level of the reservoir increases, flooding the marginal vegetation, previously dry, increasing the area of occupation of preys (insects, mollusks and shrimps), which makes it difficult to capture these items. In this period, occurs the addition of items of allochthonous origin, such as plant material and terrestrial arthropods, that fall on the surface of the body of water, depending on the degree of marginal vegetation cover (Silva et al 2012). The opposite occurs during drought, when water levels recede, exposing previously submerged areas, decreasing habitat diversity, making prey more vulnerable and facilitating capture.

These changes in the availability of food resources are an important aspect related to the trophic structure, since they can cause changes in the diet of the fish or even their trophic guild. As in the cases of $L$. piau registered as herbivore in the Pau dos Ferros and Santa Cruz reservoirs; and as omnivore in the Jiqui Lagoon. Astyanax bimaculatus recorded as an insectivorous in the Boa Cicca Lagoon (Canan et al 1997) and as herbivorous in the Santa Cruz reservoir (Oliveira et al 2016b). Recently, in a study developed by Oliveira et al (2016a) in the Pau dos Ferros reservoir, the hypothesis was confirmed that the decrease in water volume and spatial differences influence the abundance of individuals in the trophic guilds. Thus, the influence of decreasing water volume affects the feeding resources and, consequently, on the diet and trophic structure of fish in semiarid ecosystems of Rio Grande do Norte state.

\section{Final considerations}

Based on the results presented, it is observed that most of the species of fish inserted in different sweet environments of Rio Grande do Norte, classified in seven trophic categories. 
Following a same food pattern, composed of resources of both autochthonous and allochthonous origin, possibly taking advantage of the most available items at any given time of the year. They also demonstrated a feeding flexibility, with species presenting generalist habit, in some cases temporarily or spatially altering their trophic category. A strategy of extreme importance for survival in neotropical environments dammed, as it widens its range of resources, allowing tolerance of more severe impacts, such as long periods of drought.

\section{Acknowledgements}

To the Coordenação de Aperfeiçoamento de Pessoal de Nível Superior (CAPES) for the doctoral scholarship granted to the first author. To the Animal Science Post-Graduate Program of Universidade Federal Rural do Semi-Árido (UFERSA) for the opportunity to perform the first author's doctorate.

\section{References}

Abelha MCF, Agostinho AA, Goulart E (2001) Plasticidade trófica em peixes de água doce. Acta Scientiarum. Biological Sciences. 23:425-434

Abujanra F, Agostinho AA, Hahn NS (2009) Effects of the flood regime on the body condition of fish of different trophic guilds in the Upper Paraná River floodplain, Brazil. Brazilian Journal of Biology. 69:459-468.

Agostinho AA, Miranda LE, Bini LM, Gomes LC, Thomaz SM, Suzuki HI (1999) Theoretical reservoir ecology and its applications. Theoretical reservoir ecology and its applications. São Carlos, International Institute of Ecology, 585p.

Agra Filho SS (2010) Conflitos ambientais e os instrumentos da política nacional de meio ambiente. Desenvolvimento e conflitos ambientais. Belo Horizonte: Editora UFMG.

Allan JD (2004) Landscapes and riverscapes: the influence of land use on stream ecosystems. Annual Riew of Ecology, Evolution, and Systematics. 35:257-284.

Andrade HTA, Nascimento RSS, Gurgel HCB, Medeiros JF (2000) Simuliidae (Diptera) integrantes da dieta de Poecilia vivípara Bloch e Schneider, 1801 (Atheriniformes; Poeciliidae) no Rio Ceará Mirim, Estado do Rio Grande do Norte, Brasil. Entomologia y Vectores. 1:119-122.

Bennemann ST, Capra LG, Galves W, Shibatta OA (2006) Dinâmica trófica de Plagioscion squamosissimus (Perciformes, Sciaenidae) em trechos de influência da represa Capivara (rios Paranapanema e Tibagi). Iheringia, Série Zoologia. 96:115-119.

Bonato KO, Delariva RL, Silva JC (2012) Diet and trophic guilds of fish assemblages in two streams with different anthropic impacts in the northwest of Paraná, Brazil. Zoologia (Curitiba). 29:27-38.

Canan B, Gurgel HCB, Nascimento RSS, Borges SAGV, Barbieri G (1997) Avaliação da comunidade de sete espécies de peixes da lagoa Boa Cicca, Nísia Floresta-RN. Revista Ceres. 44:604-616.

Capra LG, Bennemann ST (2009) Low feeding overlap between Plagioscion squamosissimus (Heckel, 1840) and Cichla monoculus
(Spix \& Agassiz, 1831), fishes introduced in tropical reservoir of South Brazil. Acta Limnologica Brasiliensia. 21:343-348.

Cardoso MML, Torelli JER, Crispim MC, Siqueira R (2012) Diversidade de peixes em poças de um rio intermitente do semi-árido paraibano, Brasil. Biotemas. 25:161-171.

Carpenter SR, Kitchell JF (1993) The Trophic Cascade in Lakes Cambridge University Press Cambridge. MA, USA Google Scholar.

Corrêa CE, Petry AC, Hahn NS (2009) Influência do ciclo hidrológico na dieta e estrutura trófica da ictiofauna do rio Cuiabá, Pantanal Mato-Grossense. Iheringia, Série Zoologia. 99:456-463.

Corrêa F, Piedras SRN (2008) Alimentação de Cyphocharax voga (Hensel, 1869) (Characiformes, Curimatidae) no arroio Corrientes, Pelotas, Rio Grande Do Sul, Brasil. Biotemas. 21:117-122.

Davies PM, Bunn SE, Hamilton SK (2008) Primary production in tropical streams and rivers. Tropical stream ecology. 23-42.

Dias TS, Fialho CB (2009) Biologia alimentar de quatro espécies simpátricas de Cheirodontinae (Characiformes, Characidae) do rio Ceará Mirim, Rio Grande do Norte. Iheringia, Serie Zoologia. 99:242-248.

Durães R, Pompeu PS, Godinho AL (2001) Alimentação de quatro espécies de Leporinus (Characiformes, Anostomidae) durante a formação de um reservatório no sudeste do Brasil. Iheringia, Série Zoologia. 90:183-191.

Ferreira Filho VP, Guerra TP, Lima MCS, Teixeira DF, Costa RR, Araújo IMS, El-Deir ACA, Moura GJ (2014) Ecomorphological patterns with diet of Plagioscion squamosissimus (Perciformes, Scianidae) in permanent reservoir in northeastern Brazil. Iheringia. Série Zoologia. 104:134-142.

Gandini CV, Sampaio FAC, Pompeu OS (2014) Hydropeaking effects of on the diet of a Neotropical fish community. Neotropical Ichthyology. 12:795-802.

Gause GF (1934) The struggle for existence. Baltimore: Williams and Wilkins Company.

Gavilan-Leandro SAC, Peretti D, Júnior JEMP, Fernandes MA, Júnior AMG (2009) Espectro alimentar e variação sazonal da dieta de Plagioscion squamosissimus (Heckel, 1840) (Osteichthyes, Sciaenidae) na lagoa do Piató, Assú, Estado do Rio Grande do Norte, Brasil. Acta Scientiarum. Biological Sciences. 31:285-292.

Godinho LR, Santos ACA (2014) Dieta de duas espécies de peixes da família Cichlidae (Astronotus ocellatus e Cichla pinima) introduzidos no rio Paraguaçu, Bahia. Biotemas. 27:83-91.

Gomiero LM, Braga FMS (2004) Feeding of introduced species of Cichla (Perciformes, Cichlidae) in Volta Grande reservoir, river Grande (MG/SP). Brazilian Journal of Biology. 64:787-795.

Goulding M (1980) The fishes and the forest: explorations in Amazonian natural history. Univ of California Press.

Gurgel HCB, Almeida RG, Barbieri G, Vieira LJS (1998) Dieta de Crenicichla lepidota Heckel, 1840 (Perciformes, Cichlidae) da lagoa Redonda, Nísia Floresta/RN. Acta Scientiarum. Biological Sciences. 20:191-194.

Gurgel HCB, Canan B (2008) Feeding of six fish species in Jiqui Lagoon, eastern coast of Rio Grande do Norte, Brazil. Acta Scientiarum. Biological Sciences. 21:243-246.

Gurgel HCB, Lucas FD, Souza LLG (2002) Dieta de sete espécies de peixes do semi-árido do Rio Grande do Norte, Brasil. Revista de Ictiologia. 10:7-16. 
Gurgel HCB, Silva NB, Lucas FD, Souza LLG (2005) Alimentação da comunidade de peixes de um trecho do rio Ceará Mirim, em Umari, Taipu, Estado do Rio Grande do Norte, Brasil. Acta Scientiarum. Animal Sciences. 27:229-233.

Gurgel JJ, Oliveira AB (1987) Efeitos da introdução de peixes e crustáceos no semi-árido do nordeste brasileiro. ESAM.

Hahn NS, Fugi R (2007) Fish feeding in Brazilian reservoirs: alterations and consequences in the early stages of colonization. Oecologia Australis. 11:469-480.

Hellawell JM, Abel RA (1971) Rapid volumetric method for the analysis of the food of fishes. Journal of Fish Biology. 3:29-37.

Higuti J, Franco GMS (2001) Identificação de invertebrados para análise de conteúdo estomacais de peixes. Maringá: UEM.

Kawakami E, Vazzoler G (1980) Método gráfico e estimativa de índice alimentar aplicado no estudo de alimentação de peixes. Boletim do Instituto oceanográfico. 29:205-207.

Lima DO, Behr ER (2010) Feeding ecology of Pachyurus bonariensis Steindachner, 1879 (Sciaenidae: Perciformes) in the Ibicuí River, Southern Brazil: ontogenetic, seasonal and spatial variations. Brazilian Journal of Biology. 70:503-509.

Loures RC, Pompeu PS (2012) Temporal variation in fish community in the tailrace at Três Marias Hydroelectric Dam, São Francisco River, Brazil. Neotropical Ichthyology. 10:731-740.

Macarthur RH, Pianka ER (1966) On optimal use of a patchy environment. The American Naturalist. 100:603-609.

Machado-Evangelista M, Esguícero ALH, Arcifa MS, Pereira TNA (2015). Diet and ecomorphology of Leporinus reticulatus (Characiformes: Anostomidae) from the upper Rio Juruena, MT, Brazil: ontogenetic shifts related to the feeding ecology. Acta Amazônica. 45:383-392.

Magalhães EM, Almeida RG, Gurgel HCB, Barbieri G (1990) Contribuição ao estudo da alimentação de Serrasalmus brandtii (Reinhardt, 1874) (Characiformes, Serrasalmidae) do rio PiranhasAçu, Pendências, Rio Grande do Norte. Ceres. 37:429-442.

Mazzeo N, Iglesias C, Teixeira-de Melo F, Borthagaray A, Fosalba C, Ballabio R, Larrea D, Vilches J, García S, Pacheco JP, Jeppesen E (2010) Trophic cascade effects of Hoplias malabaricus (Characiformes, Erythrinidae) in subtropical lakes food webs: a mesocosm approach. Hydrobiologia. 644:325-335.

Mazzoni R, Moraes M, Rezende CF, Iglesias-Rios R (2010) Diet and feeding daily rhythm of Pimelodella lateristriga (Osteichthyes, Siluriformes) in a coastal stream from Serra do Mar-RJ. Brazilian Journal of Biology. 70:1123-1129.

McCafferty WP (1981) Aquatic entomology. Jones and Bartlett Publishers, Inc. USA, Boston.

Medeiros TN, Rocha AA, Santos NC, Severi W (2014) Influence of the hydrological level on the diet of Leporinus reinhardtii (Characiformes, Anostomidae) in a semi-arid Brazilian reservoir. Iheringia. Série Zoologia. 104:290-298.

Mendes LB, Borges JAT, Silva MJ, Costa Ramos RT, Medeiros ESF (2013) Food habits of Triportheus signatus (Teleostei, Characidae) in a Brazilian semi-arid intermittent river. Revista Brasileira de Zoociências. 13:59-71.

Mérona B, Vigouroux R (2006) Diet changes in fish species from a large reservoir in South America and their impact on the trophic structure of fish assemblages (Petit-Saut Dam, French Guiana). In: Annales de Limnologie-International Journal of Limnology. EDP Sciences. 53-61.
Merritt RW, Cummins KW (1996) An introduction to the aquatic insects of North America. Kendall Hunt.

Molina WF, Gurgel HCB, Vieira LJS, Canan B (1996) Ação de um predador exógeno sobre um ecossistema aquático equilibrado. I. Extinções locais e medidas de conservação genética. Revista Unimar. $18: 335-345$.

Montenegro AKA, Torelli JER, Araújo Marinho RS, Crispim MC, Hernandez MIM (2010) Aspects of the feeding and population structure of Leporinus piau Fowler, 1941 (Actinopterygii, Characiformes, Anostomidae) of Taperoá II Dam, semi-arid region of Paraíba, Brazil. Biotemas. 23:101-110.

Montenegro LA, Damasceno DNF, Almeida RG, Chellappa S (2011) Biologia alimentar do mussum, Synbranchus marmoratus (Bloch, 1795) (Osteichthyes: Synbranchidae) no açude Marechal Dutra localizado no semi-árido brasileiro. Biota Amazônia. 1:45-52.

Novaes JLC, Caramaschi EP, Winemiller KO (2004) Feeding of Cichla monoculus Spix, 1829 (Teleostei: Cichlidae) during and after reservoir formation in the Tocantins River, Central Brazil. Acta Limnologica Brasiliensia. 16:41-49.

Novaes JLC, Moreira SIL, Freire CEC, Sousa MMO, Costa RS (2014) Fish assemblage in a semi-arid Neotropical reservoir: composition, structure and patterns of diversity and abundance. Brazilian Journal of Biology. 74:290-301.

Novakowski GC, Hahn NS, Fugi R (2007) Alimentação de peixes piscívoros antes e após a formação do reservatório de Salto Caxias, Paraná, Brasil. Biota Neotropica. 7:149-154.

Oliveira JCD, Oliveira JF, Rebouças LGF, Novaes JLC, Peretti D (2018) Does the oscillation of the water volume of the reservoir influence in the same way, in fish diet? Acta Limnologica Brasiliensia. 30.

Oliveira JF, Costa RS, Novaes JLC, Rebouças LGF, Morais-Segundo ALN, Peretti D (2016a) Efeito da seca e da variação espacial na abundância de indivíduos nas guildas tróficas da ictiofauna em um reservatório no Semiárido Brasileiro. Boletim do Instituto de Pesca. 42:51-64.

Oliveira JF, Morais Segundo ALN, Novaes JLC, Costa RS, França JS, Peretti D (2016b) Estrutura trófica da ictiofauna em um reservatório do semiárido brasileiro. Iheringia Série Zoologia. 106:19.

Pessoa EKR, Lima LTB, Chellappa NT, Souza AA, Chellappa S (2013) Aspectos alimentares e reprodutivos do cascudo, Hypostomus pusarum (Starks, 1913) (Osteichthyes: Loricariidae) no açude Marechal Dutra, Rio Grande do Norte, Brasil. Biota Amazônia. 3:45-53.

Petry AC, Abujanra F, Gomes LC, Julio Jr HF, Agostinho AA (2006) Effects of the interannual variations in the flood pulse mediated by hypoxia tolerance: the case of the fish assemblages in the upper Paraná River floodplain. Neotropical Ichthyology. 11:413-424.

Pompeu OS, Godinho HP (2006) Effects of extended absence of flooding on the fish assemblages of three floodplain lagoons in the middle São Francisco River, Brazil. Neotropical Ichthyology. 4:427433.

Raposo RMG, Gurgel HCB (2003) Variação da alimentação natural de Serrasalmus spilopleura Kner, 1860 (Pisces, Serrasalmidae) em função do ciclo lunar e das estações do ano na lagoa de Extremoz, Rio Grande do Norte, Brasil. Acta Scientiarum. Animal Sciences. 25:267-272. 
Ribeiro AR, Biagioni RC, Smith WS (2014) Study of the natural diet of the fish fauna of a centenary reservoir, São Paulo, Brazil. Iheringia. Série Zoologia 104:404-412.

Rosa RS, Menezes NA, Britski HA, Costa WJEM, Groth F (2003) Diversidade, padrões de distribuição e conservação dos peixes da Caatinga. Ecologia e conservação da Caatinga.

Ross ST (1986) Resource partitioning in fish assemblages: a review of field studies. Copeia. 352-388.

Santana Filho JR (2008) Projeto São Francisco: garantia hídrica como elemento dinamizador do Semi-árido. Inclusão Social. 2:2.

Santos AFGN, Carrera PRO, Aronovich M, Santos LN (2014) Preferência alimentar de juvenis de lambari-cachorro, Oligosarcus hepsetus, em relação a duas espécies de presas de peixe em ambiente controlado. Ciência Rural. 44:307-313.

Santos NCL, Nascimento Medeiros T, Rocha AAF, Dias RM, Severi W (2014) Uso de recursos alimentares por Plagioscion squamosissimus - piscívoro não-nativo no reservatório de Sobradinho-BA, Brasil. Boletim do Instituto de Pesca. 40:397-408.

Silva CC, Ferreira EJG, Deus CP (2008) Dieta de cinco espécies de Hemiodontidae (Teleostei, Characiformes) na área de influência do reservatório de Balbina, rio Uatumã, Amazonas, Brasil. Iheringia, Série Zoologia. 98:464-468.

Silva DA, Pessoa EKR, Costa SAGL, Chellappa NT, Chellappa S (2012) Ecologia alimentar de Astyanax lacustris (Osteichthyes: Characidae) na Lagoa do Piató, Assú, Rio Grande do Norte, Brasil. Biota Amazônia. 2:74-82.

Silva GA, Souza BB, Silva EMN (2015) Adaptabilidade de ovinos e estratégias para minimizar os efeitos do clima em regiões tropicais. Journal of Animal Behaviour and Biometeorology. 3:20-27.

Silva JC, Delariva RL, Bonato KO (2012) Food-resource partitioning among fish species from a first-order stream in northwestern Paraná, Brazil. Neotropical Ichthyology. 10:389-399.

Sousa MMO (2015) Composição e estrutura temporal da ictiofauna do reservatório de Santa Cruz, rio Apodi/Mossoró, semiárido brasileiro. Dissertação, mestrado em Ciência Animal, Universidade Federal Rural do Semi-Árido.

Souza AEF, Oliveira JF, Peretti D, Fernandes R, Costa RS, Novaes JLC (2017) Effects of a Supraseasonal Drought on the Ecological Attributes of Plagioscion squamosissimus (Heckel, 1840) (Pisces, Sciaenidae) in a Brazilian Reservoir. The Scientific World Journal. 2017:1-9.

Stefani PM, Rocha O (2009) Diet composition of Plagioscion squamosissimus (Heckel, 1840), a fish introduced into the Tietê River system. Brazilian Journal of Biology. 69:805-812.

Teixeira JLA, Gurgel HCB (2004) Dinâmica da nutrição e alimentação natural de Steindachnerina notonota (Miranda-Ribeiro, 1937) (Pisces, Curimatidae), Açude de Riacho da Cruz, Rio Grande do Norte, Brasil. Revista Brasileira de Zoociências. 6:19-28.

Tófoli RM, Hahn NS, Alves GH, Novakowski GC (2010) Uso do alimento por duas espécies simpátricas de Moenkhausia (Characiformes, Characidae) em um riacho da Região Centro-Oeste do Brasil. Iheringia, Série Zoologia 100:201-206.

Velludo MR (2007) Ecologia trófica da comunidade de peixes do reservatório do Lobo (Broa), Brotas-Itirapina/SP, com ênfase à introdução recente da espécie alóctone Cichla kelberi (Perciformes, Cichlidae). Dissertação, Universidade Federal de São Carlos.
Vieira A, Santos V, Curi W (2010) Escolha das Regras de Operação Racional para Subsistema de Reservatórios no Semiárido Nordestino. Engenharia Ambiental: Pesquisa e Tecnologia. 7:37-50.

Vitule JRS (2009) Introdução de peixes em ecossistemas continentais brasileiros: revisão, comentários e sugestões de ações contra o inimigo quase invisível. Neotropical Biology and Conservation. 4:111-122.

Winfield IJ (2004) Fish in the littoral zone: ecology, threats and management. Limnologica - Ecology and Management of Inland Waters. 34:124-131.

Ximenes LQL, Fatima Mateus LA, Penha JMF (2011) Variação temporal e espacial na composição de guildas alimentares da ictiofauna em lagoas marginais do Rio Cuiabá, Pantanal Norte. Biota Neotropica. 11:205-216.

Young PS, Cech JJ, Thompson LC (2011) Hydropower-related pulsed-flow impacts on stream fishes: a brief review, conceptual model, knowledge gaps, and research needs. Reviews in Fish Biology and Fisheries. 21:713-731.

Zohary T, Ostrovsky I (2011) Ecological impacts of excessive water level fluctuations in stratified freshwater lakes. Inland Waters. 1:4759. 